Folia primat. 1971;15:I-IV

\title{
Contents, Vol. 15, 1971
}

\section{Editor:}

J. Biegert, Zurich

Editorial Board:

E. L. Bone, Louvain

W. Fiedler, Wien

H. F. Harlow, Madison, Wise.

H. Hediger, Zurich

W. C. Osman Hill, Folkestone

H. Hofer, Covington, La.

J. Hürzeler, Basel

J. R. Napier, London

J. Piveteau, Paris

A. Remane, Kiel

A. H. Schultz, Zurich

D. Starck, Frankfurt am Main

W. L. Straus, Jr., Baltimore, Md.

S. L. Washburn, San Francisco, Calif.

H. Zapfe, Wien

S. Zuckerman, Birmingham

\section{$\mathrm{S} 7 / 8 \mathrm{fK}$}

\section{S. Karger}

Basel $\cdot$ München $\cdot$ Paris $\cdot$ London $\cdot$ New York $\cdot$ Sydney

S. Karger · Basel · München · Paris · London · New York · Sydney Amold-Böcklin-Strasse 25, CH-4000 Basel 11 (Switzerland)

All rights, including that of translation into other languages, reserved. Photomechanic reproduction (photocopy, microcopy) of this volume or parts thereof without special permission of the publishers is prohibited.

(C) Copyright 1971 by S. Karger AG, Verlag für Medizin und Naturwissenschaften, Basel Printed in Switzerland by Schellenberg-Druck, Pfäffikon ZH

Contents

Aldrich-Blake, F. P. G.; Bunn, T. K.; Dunbar, R. I. M., and Headley, P. M.:

Observations on Baboons, Papio anubis, in an Arid Region in Ethiopia 1

Angst, R. und Mann, P.: Zur Variabilität von Urogaíe everetti 148

Antonius, J. I.; Ferrier, Simone A., and Dillingham, L. A.: Pulmonary Embolus

and Testicular Atrophy in a Gorilla 277 
Barnicot, N. A. and Hewett-Emmett, D.: Red Cell and Serum Proteins of Talapoin,

Patas and Vervet Monkeys 65

Benjamin, S. A.: vide Brumback, R. A.

Brumback, R. A.; Staton, R. D.; Benjamin, S. A., and Lang, C. M.: The Chromosomes of Aotus

trivirgatus Hamboldt 1812 (with 1 fold-out plate) .... 264

Bunn, T. K.: vide Aldrich-Blake, F. P. G.

Crook, J. H.: vide Deag, J. M.

Deag, J. M. and Crook, J. H.: Social Behaviour and 'Agonistic Buffering' in the

Wild Barbary Macaque Macaca sylvana L 183

Dillingham, L. A.: vide Antonius, J. I.

Dunbar, R. I. M.: vide Aldrich-Blake, F. P. G.

Egozcue, J.: A Note on the Chromosomes of Aotus trivírgatus Humboldt 1812 . . 274

Ferrier, Simone A.: vide Antonius, J. I.

Grau, M.: vide Planas, J.

Hamilton, W. J., 111: vide Tenaza, R. R.

Headley, P. M.: vide Aldrich-Blake, F. P. G.

Hewett-Emmett, D.: vide Barnicot, N. A.

Hofer, H. O.: On the Recessus Mesocoelicus in some Primates 249

Hunkeler, P.: vide Struhsaker, T. T.

Klein, L. L.: Observations on Copulation and Seasonal Reproduction of Two Species of Spider Monkeys, Ateíes belzebuth and A. geoffroyi 233

Lancaster, Jane B.: Play-mothering: The Relations between Juvenile Females and Young Infants among Free-ranging Vervet Monkeys (Cercopithecus

aethiops) $\quad 161$

Lang, C. M.: vide Brumback, R. A.

Lorenz, R.: Goeldi's Monkey Callimico goeldii Thomas 1904 Preying on Snakes 133

Mann, P.: vide Angst, R.

Menzel, E. W., Jr.: Communication about the Environment in a Group of Young

Chimpanzees 220

Planas, J. and Grau, M.: Serum Chemistry in the Chimpanzee and the Gorilla. . 77

Roberts, J. A. and Wolf, R. H.: Hydronephrosis of Pregnancy: a Naturally Occurring Disorder in Non-human Primates Closely Resembling that in Man 143

Rohles, F. H., Jr.: Social Entrainment of the Feeding Behavior in Monkeys . ... 58

Saayman, G. S.: Behaviour of the Adult Males in a Troop of Free-ranging Chacma

Baboons (Papio ursinus) 36

Schön, M. A.: The Anatomy of the Resonating Mechanism in Howling Monkeys 117

IV

Contents

Severson, Anita : vide Tappen, N. C.

Staton, R. D.: vide Brumback, R. A.

Struhsaker, T. T. and Hunkeler, P.: Evidence of Tool-using by Chimpanzees in the Ivory Coast 212

Tappen, N. C. and Severson, Anita : Sequence of Eruption of Permanent Teeth and Epiphyseal Union in New World Monkeys 293

Tenaza, R. R. and Hamilton, W. J., 111: Preliminary Observations of the Mentawai Islands Gibbon, Hylobates klossii 201 
Uhlmann, K.: Die phylogenetische Entwicklung der Hüft- und Oberschenkelmuskulatur der Primaten

Wolf, R. H.: vide Roberts, J. A.

Announcements - Mitteilungen - Communications 159

Book Reviews - Buchbesprechungen - Livres nouveaux 